\title{
PSicopatología DE LA CORRUPCIÓN
}

\author{
Psychopathology of corruption
}

Martín Nizama Valladolid ${ }^{1}$

\section{RESUMEN}

Se elabora una sistematización fenomenológica de la corrupción; grave proceso mórbido espiritual, cuya génesis se remonta a los orígenes de la humanidad. Actualmente es una pandemia en la sociedad anética y deshumanizada, regida más por los antivalores. En el Perú, la corrupción no tuvo registro en la Época del Tahuantinsuyo. Esta se inició en la Época Colonial con la presencia de los conquistadores, quienes la introdujeron en la sociedad peruana; y continuó en la Época Republicana hasta la actualidad, habiéndose convertido en un grave problema de salud espiritual, con impacto devastador en todos los campos de la realidad social, hasta convertirse en un factor de desestabilización del Estado y de ingobernabilidad. Seguidamente se presenta el perfil psicosocial disfuncional del peruano; se formula una definición de la corrupción como un grave trastorno espiritual, en el cual el individuo carece de conciencia del daño que ocasiona a sus semejantes. Se abordan sus características, etiología, fenomenología y estructura. También, se mencionan los diversos escenarios de la corrupción, sus principales manifestaciones, la institucionalidad disfuncional en sus formas aberrantes: La institucionalidad informal y la institucionalidad oculta. Luego se describe la cultura escatológica, el lenguaje de la corrupción con las expresiones más comunes del acervo popular y la imagenología de las cúpulas dirigentes. Así como el síndrome de la corruptela política, la semiología correspondiente y las secuelas de la corrupción. Finalmente, unas reflexiones sobre este trastorno y las alternativas pertinentes con el propósito de contribuir a erradicarlo del seno de la sociedad.

Palabras clave: Corrupción, psicopatía social, comportamiento anético.

\begin{abstract}
A phenomenologic systematization of corruption is built. Corruption is a serious spiritual morbid process, whose genesis starts with the origin of humanity. Nowadays, it's pandemic in a anethic and dehumanized society, which is ruled by anti values. In Peru, corruption has not been registered during the Inca empire. It began with the Colony, when conquerors seed it in our society, and it has continued through the Republican period and until our days. It has become a serious problem for our spiritual health, with devastating impact in every field of our social reality, it has become a destabilizing factor for the state and its governability. A dysfunctional psicosocial profile of Peruvians is explained and corruption is defined as a serious spiritual disturbance, in which an individual suffers a lack of consciousness of the damage caused to his fellowmen. Characteristics, etiology, phenomenology and
\end{abstract}

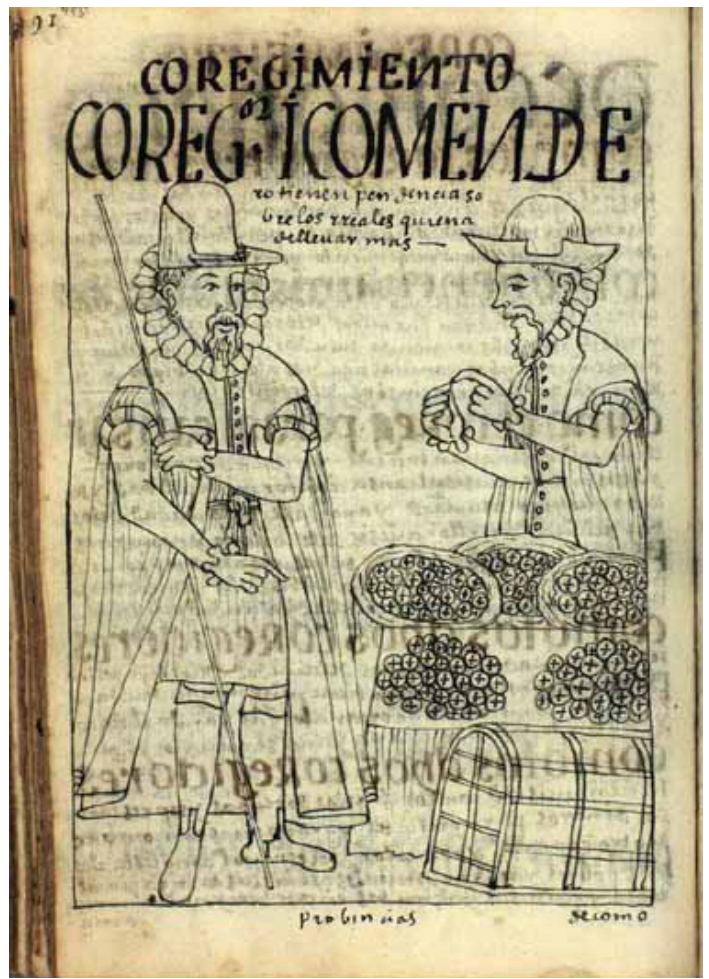

COREG[ID]OR I COMENDEro tienen pendencia sobre los rreales, quién a de lleuar más.

Guaman Poma, Nueva corónica y buen gobierno (1615)

Fuente: http:/ /www.kb.dk/permalink/2006/poma/495/es/image/

structure are discussed. Also, the different stages of corruption, its main manifestations, the dysfunctional institutionality in its aberrant forms. The informal and hidden institutionality and the eschatological culture are described, also, the most common expressions of corruption's language and the image of corrupted leaders, as well as the syndrome of corrupted politics, its semiology and its consequences. Finally, some reflections of this disturbance and appropiate alternatives with the purpose of contributing to the eradication of corruption from the core of society.

Keywords: Corruption, social psycopathy, anethic behavior.

1 Médico psiquiatra. Profesor principal de los Departamentos Académicos de Psiquiatría de la de la Universidad Peruana Cayetano Heredia y de la Universidad Nacional Mayor de San Marcos. 
INTRODUCCIÓN

a corrupción es un cáncer espiritual que corroe las entrañas más profundas de la humanidad, con grave impacto en el desarrollo humano y en desmedro del capital social en la "pequeña aldea global". Es un fenómeno anético y amoral estructural, sistemático y generalizado que afecta de manera devastadora al Estado, las instituciones, la célula familiar y al individuo, con secuelas degradantes y disruptivas. Sus elevados índices la han convertido en uno de los más grandes problemas de la posmodernidad, si no el mayor, por el daño económico, político, ético y moral que acarrea en la población mundial y nacional.

Sus inicios se remontan a los orígenes de la humanidad. La Biblia relata la felonía de Judas quien vendió a Jesús por unas cuantas monedas. Las mil y una noches, los libros de Los vedas, Los diálogos socráticos, La Ilíada, La Odisea, La Eneida, El ingenioso Caballero don Quijote de la Mancha, El Criticón y La Divina Comedia, entre otras obras de la literatura clásica, refieren hechos de corrupción. Por ejemplo, Shakespeare, refiriéndose a la corrupción hizo decir a Hamlet: "algo se pudre en Dinamarca". También, en la concepción cristiana, los siete pecados capitales (la soberbia, la avaricia, la envidia, la ira, la lujuria, la gula y la pereza) tienen relación directa con la corrupción.

En la posmodernidad está en auge la sociedad anética, en la cual prevalecen los antivalores: vacuidad, codicia, saciamiento, facilismo, utilitarismo, hedonismo, odio, envidia, narcisismo, insensibilidad, banalidad, violencia y corrupción global. La sociedad anética es narcisista, materialista y deshumanizada, adherida a la vida de apariencia, la banalidad y los estereotipos mentales, en la cual tiene plena vigencia el pensamiento de Francisco de Quevedo y Villegas (1580-1645): “Poderoso caballero es don dinero".

Incluso, Gianfranco Girotti, arzobispo del Vaticano en una homilía del 2008 propuso los Siete Pecados Sociales del Mundo Posmoderno: 1. Modificación genética, 2. Experimentación con seres humanos, 3. Contaminación ambiental, 4. Injusticia social, 5. Generación de pobreza, 6. Ambición financiera, y 7. Drogadicción. En el mismo sentido el Mahatma Gandhi, señaló los Factores que Destruyen al Ser Humano: 1. Política sin principios, 2. Riqueza sin trabajo, 3. Placer sin compromiso, 4. Sabiduría sin carácter, 5. Ciencia sin humanidad, 6. Negocios sin moral, y 7 . Oración sin caridad.

Por lo demás, es conocido que en el quehacer de la política cotidiana existe un axioma: Política, poder, dinero, corrupción y lujuria van siempre de la mano, de espaldas al pudor. En ella, según Macchiavello, con la argucia de la razón de Estado, el fin justifica los medios. En este contexto, cabe parafrasear a Martin Luther King: "No me preocupa el grito de los violentos, de los corruptos, de los deshonestos, de los sin ética. Lo que más me preocupa es el silencio de los buenos". Entre nosotros, Saúl Peña, desde la perspectiva psicoanalítica apunta: "El traumatismo histórico, la cultura del crimen, la tortura y la corrupción dan lugar a una patología del lazo social. Es obligación nuestra hacer escuchar a la sociedad y a la humanidad lo que ella no está dispuesta a escuchar y no quiere creer". [1]

En la historia nacional, durante el Tahuantinsuyo (S. XII-S. XVI) se creó un eficaz muro de contención anticorrupción mediante la aplicación implacable de tres principios ético-morales: Ama sua, no seas ladrón; Ama quella, no seas flojo y Ama llulla, no seas mentiroso. Sin embargo, el historiador peruano Raúl Porras Barrenechea señala que en la época de Inca Huayna Cápac se inicia la decadencia del Tahuantinsuyo. Este Inca era 
un gran conquistador como su padre, Túpac Yupanqui, y su abuelo, Pachacútec, más, en él se presentan y se afirman los síntomas de una corrupción en el incanato. Luego de la gran expansión confederativa, la nobleza incaica encabezada por Huayna Cápac había formado una casta exclusiva, corrupta y excluida del trabajo. El pueblo trabajaba las tierras del inca, del Sol y de la comunidad, pero además se les obligaba a hacer producir las tierras de la élite parásita que les exigía en pago cierta parte de los productos de la cosecha.

El pueblo admiraba a los grandes espíritus guerreros y conquistadores como lo de los incas Pachacútec, Túpac Yupanqui y, sobre todo, a la casta sobria y virtuosa de los Orejones hasta que estos perdieron su mística, los Orejones ya no comían maíz crudo ni viandas sin sal, no se abstenían de mujer, no realizaban trabajos de mano, ni eran los primeros en salto y carrera, sólo conservaban el amor a la chicha. Tras la conquista del Reino de Quito la unidad del Tahuantinsuyo comenzó a resquebrajarse, el odio entre las castas cuzqueñas y quiteñas era irreconciliable. Huayna Cápac era vicioso de mujeres y el primer borracho del reino, sus hijos Atahualpa y Huáscar, sedientos de poder, iniciaron la guerra civil y con ella las intrigas y felonías que los pusieron a merced de los conquistadores españoles. [2]

En la Época Colonial (1522-1821), se inicia la corrupción cuando en la ciudad de Toledo, el 26 de julio de 1529, la Reyna Isabel (de Portugal), esposa del Rey Carlos V firmó la capitulación con Francisco Pizarro, dándole al conquistador los mismos poderes que poseía el Rey. De modo que los funcionarios que llegaron a América estuvieron investidos con el mismo poder que ostentaba el monarca. Es más, los corregidores, encomenderos y demás delegados de la corona se regían por el apotegma: Acato la ley pero no la cumplo. Así, tuvieron licencia para cometer todo tipo de tropelías, perversidades e iniquidades. Por ejemplo, el engaño de Pizarro al Inca Atahualpa, el embuste religioso del cura Valverde, la doble moral de la Iglesia Católica, las atrocidades de la Inquisición, la subasta de cargos públicos, cobros subrepticios, impuestos abusivos, la ominosa esclavitud; así como la inicua explotación del indio, el envilecimiento de la población aborigen y el genocidio de más de 12 millones de indígenas. [3]

En la Época Republicana (1821-2008), los pensadores peruanos desnudaron la corrupción de la manera siguiente: Gonzales Prada afirmó, "En el Perú, donde se pone el dedo brota la pus" y dejó para la posteridad esta catilinaria, "Acabemos con el pacto infame de hablar a media voz". Jorge Basadre: "El Perú carece de clase dirigente; sólo tiene clase dominante"; la malversación del Tesoro Público, en "Lima fue grande y en provincias monstruosos"; y Mario Vargas Llosa, en su libro Conversación en la Catedral, a través de su personaje Zavalita se pregunta: "¿En qué momento se jodió el Perú?". Y, en la actualidad, con proverbial vergüenza, podemos sentenciar que los peruanos nadamos en la pus de la corrupción. [1,4-8] De modo que este trastorno mórbido en el Perú es un lastre de antigua data, cebada por la codicia, impudicia, impunidad, lenidad y la complicidad.

Entre tanto, el perfil psicosocial disfuncional del peruano es como sigue: inmadurez, amnesia, huachafería, conformismo, mediocridad, desidia, impuntualidad, desorganización, improvisación, imprevisión, mesianismo, sumisión, actitud pasivo-agresiva, desconfianza, desesperanza, fatalismo, facilismo, oportunismo, arribismo, envidia, chisme, intriga, maltrato y revanchismo. Un vasto caldo de cultivo para la corrupción en una población vulnerable. 


\section{Etimología}

La palabra corrupción tiene su origen en el vocablo latín corruptio: pérdida de la esencia por putrefacción, daño o perversión de un objeto o valor.

\section{Sinonimia}

Cáncer espiritual. Gangrena moral. Podredumbre. Hedor social. Argolla. Cúpula. Amarre. Amiguismo.

\section{Definición}

La corrupción es un grave trastorno espiritual que consiste en la corrosión ética y moral, personal, grupal y social, con la consecuente perversión del pensamiento, la conducta y la sensualidad. Su propósito es el beneficio personal y/o grupal, en desmedro del interés social. Es cebada por el egoísmo, la codicia, mezquindad, estulticia y el cinismo; sin conciencia del daño que se ocasiona al prójimo ni de las secuelas que se causan a la sociedad o a la nación.

\section{Características}

Daño de la integridad, virtud o principios morales; inducir a lo incorrecto por métodos ilegales; utilización del poder político o de los privilegios de un cargo público para conseguir beneficios personales y hacer amoral a una persona, costumbre o tradición.

\section{Leyes de la corrupción}

Nace del vértice del poder.

Sus móviles son el poder, la codicia y la concupiscencia.

Es incubada por la impunidad, la lenidad, la inacción, el silencio cómplice, el encubrimiento y la perversión de la legalidad.
Corroe la moral social.

Es metastásica.

Devastador poder disruptor del tejido social.

Causa secuelas pero no deja huella.

El tesoro público, los recursos naturales y las actividades extractivas son el botín y fuente de poder anético.

\section{Etiología}

La corrupción es un fenómeno mórbido, complejo, multicausal, entre las cuales cabe mencionar las siguientes: Codicia, narcisismo, lujuria, Impunidad, lenidad, desamor, egolatría, vacío espiritual, avaricia, sensualidad, escala axiológica débil/ausente, paradigmas negativos, conflicto de intereses, permisividad, tolerancia social, silencio cómplice y búsqueda de dinero fácil y / o poder.

\section{Fenomenología}

Su esencia es la carencia o debilidad de la escala axiológica a la cual se adiciona el desamor al prójimo, la avaricia, la lujuria y la egolatría. Por este motivo, la corrupción es un proceso mórbido de índole espiritual, económica, social y cultural solapado, insondable e irreductible, por acción de quienes lo practican en forma activa o pasiva, apoyados por el silencio cómplice y por soterradas redes de clientelismo, corrosivas; circuitos o grupos de poder omnímodo, chantajista y extorsionador. Es orquestada por los hilos invisibles del arte del engaño, la manipulación, la seducción y la maquinación. [7-11]

\section{Estructura}

Los componentes de la estructura de este fenómeno mórbido son:

Corrosión ética y moral, activa y pasiva. Estrategias y logística. Redes enmascaradas. 
Redes de apoyo. Silencio e impunidad. Cultura escatológica. Lenguaje propio.

Escenarios de la corrupción

Existen diversos escenarios de corrupción:

$\begin{array}{lll}\text { Personal } & \text { Empresarial } & \text { Religiosa } \\ \text { Familiar } & \text { Comercial } & \text { Profesional } \\ \text { Social } & \text { Judicial } & \text { Mediática } \\ \text { Política } & \text { Policial } & \text { Gremial } \\ \text { Gubernamental } & \text { Castrense } & \text { Institucional } \\ \text { Burocrática } & \text { Académica } & \text { Virtual }\end{array}$

\section{Operadores de la corrupción}

La corrupción utiliza una vasta variedad de operadores:

$\begin{array}{ll}\text { Testaferros } & \begin{array}{l}\text { Torturadores } \\ \text { "Cortinas": Individuos } \\ \text { "Lobbistas" }\end{array} \\ \begin{array}{l}\text { "Comandractores } \\ \text { Contactos }\end{array} \\ \text { Infiltrados } & \text { Peones } \\ \text { Asesores } & \text { Extorsionadores } \\ \text { Padrinos } & \text { "Chuponeadores" } \\ \text { Clanes } & \text { Sicarios } \\ \text { familiares } & \text { "Abogánsters" }\end{array}$

\section{Manifestaciones}

Las principales manifestaciones de la corrupción son:

$\begin{array}{ll}\text { Espionaje } & \text { Enriquecimiento ilícito } \\ \text { Soborno } & \text { Prevaricato } \\ \text { Extorsión } & \text { Concusión } \\ \text { Tráfico de influencias } & \text { Nepotismo } \\ \text { Lobbies } & \text { Fraude } \\ \text { Lavado de dinero } & \text { Secretismo } \\ \text { Tráfico ilícito de } & \text { Compra de puestos } \\ \text { drogas } & \text { públicos }\end{array}$

\begin{tabular}{ll} 
Redes invisibles & Impudicia \\
$\begin{array}{l}\text { Institucionalidad } \\
\text { aberrante }\end{array}$ & Oportunismo \\
$\begin{array}{l}\text { Tráfico de armas } \\
\begin{array}{l}\text { Corrupción de } \\
\text { funcionarios }\end{array}\end{array}$ & Aprovechamiento \\
\hline
\end{tabular}

\section{Perfil psicopático del corrupto}

El corrupto es un psicópata enmascarado. Comúnmente presenta:

$\begin{array}{ll}\text { Soberbia } & \text { Prepotencia } \\ \text { Apetencia del poder } & \text { Seducción } \\ \text { Mendacidad } & \text { Simulación } \\ \text { Cinismo } & \text { Manipulación } \\ \text { Insensibilidad } & \text { Maquinación } \\ \text { Avaricia } & \text { Locuacidad } \\ \text { Doble moral } & \text { Histrionismo } \\ \text { Doble vida } & \text { Narcisismo } \\ \text { Negación irreductible } & \text { Enmascaramiento } \\ \text { Comportamiento } & \text { Propensión mafiosa } \\ \text { avezado } & \text { Ausencia de autocrítica } \\ \text { Blindaje legal } & \\ \text { Carencia de } & \text { Opulencia escandalosa } \\ \text { sentimiento de culpa } & \\ \begin{array}{l}\text { Inconsciencia del daño } \\ \text { que ocasionan. }\end{array} & \end{array}$

\section{Trastorno de personalidad antisocial: Subtipo codicioso}

Características narcisistas. Predominan la grandezayeldeseo de dominary poseer.Sienten que han sido privados intencionadamente de lo suyo. Deseo de compensar el vacío que experimentan con bienes materiales o poder. Voraces, escatimadores, envidiosos, avaros, despilfarradores, ostentosos. [12] 


\section{Institucionalidad disfuncional}

La débil institucionalidad formal o convencional tiene su contraparte aberrante:

\section{- La institucionalidad informal}

Constituida por personal acostumbrado a proceder según su criterio y en función de sus intereses personales, al margen de la legalidad y de la normatividad vigente. Su poder es fuerte y suele imponerse a la institucionalidad convencional, mediante la argucia, las malas artes, la presión sostenida y la manipulación por parte de cúpulas anéticas de toda calaña.

\section{- La institucionalidad oculta}

Conformada por grupos y redes solapadas de poder mafioso, cuyo propósito es apoderarse de las instituciones para depredarlas en beneficio particular, poniendo la institucionalidad al servicio de su insaciable codicia en desmedro de los intereses de la institución que representan. Son avezados en el arte de la guerra psicológica, la guerra sucia y el acogotamiento vil de autoridades. Es el hedor, el agujero negro de la institucionalidad disfuncional. Su poder es maligno.

\section{- La cultura escatológica}

Se le define como la expresión de la miseria humana en sus niveles más abyectos y repulsivos, al servicio del odio, la envidia, la avaricia y la mezquindad más ruin. Se expresa mediante libelos anónimos, voladas, rumor, denigración, infamación, intriga y chisme. También se le denomina cultura cloacal, cultura de zaguán o coprocultura.

\section{Tipos de Estado}

La corrupción es propicia para el surgimiento de estados disfuncionales o anómicos como:

- Estado perverso

Gobierna en perjuicio del pueblo, no en su beneficio. Cúpula gubernamental que se perpetúa en el poder.Hampa políticoseapodera del Estado, saqueándolo. Masiva migración externa en busca de oportunidades. Terrorismo de Estado. Genocidios, desapariciones forzadas, cementerios clandestinos. Pobreza, intimidación social y desesperanza.

- NarcoEstado

Es la infiltración del narcopoder en las estructuras del Estado nacional, regional, municipal e institucional. Lo constituyen:

\begin{tabular}{|c|c|}
\hline Penetración de los cárteles & Embuste \\
\hline Narcotráfico (TID) & Amenaza \\
\hline Crimen organizado & Chantaje \\
\hline $\begin{array}{l}\text { Lavado de activos, } \\
\text { "blanqueo" }\end{array}$ & Extorsión \\
\hline $\begin{array}{l}\text { Cooptación de } \\
\text { autoridades }\end{array}$ & Ajuste de cuentas \\
\hline $\begin{array}{l}\text { Mafias del TID } \\
\text { enquistadas en el aparato } \\
\text { administrativo }\end{array}$ & $\begin{array}{l}\text { Impunidad/Lenidad/ } \\
\text { Inacción } \\
\text { Uso perverso del } \\
\text { marco legal... }\end{array}$ \\
\hline $\begin{array}{l}\text { Narcoempresas } \\
\text { contratantes con el Estado }\end{array}$ & $\begin{array}{l}\text { Campañas mediáticas } \\
\text { para legalizar drogas } \\
\text { ilícitas }\end{array}$ \\
\hline Lobbyng & Empresas de fachada \\
\hline Narcopolítica & $\begin{array}{l}\text { Narcocadenas de } \\
\text { negocios }\end{array}$ \\
\hline Narcodemocracia & $\begin{array}{l}\text { Fortunas depositadas } \\
\text { en paraísos }\end{array}$ \\
\hline Narcopartidos & $\begin{array}{l}\text { financieros: empresas } \\
\text { offshore }\end{array}$ \\
\hline
\end{tabular}


Narcocandidatos Territorios liberados para el cultivo de drogas ilícitas

Narcoelecciones

Cárceles: antros y guaridas

\section{Estado Fallido}

Estado débil: poco o nulo control efectivo sobre su territorio, incapaz de prodigar educación, salud, seguridad y bienestar a la población, con perversión de la ética y la moral en las entidades públicas. Corroído por la corrupción desde el vértice del poder hasta la base social. Empoderamiento de la mediocrecracia con desprecio a la meritocracia. Inaplicación de las leyes, alto índice de criminalidad, corrupción y burocracia insensible con muy pobre nivel educativo de la población y prevalencia del mercado negro. [13]

\section{Lenguaje de la corrupción}

Las expresiones idiomáticas de mayor arraigo popular relacionadas con la corrupción son, entre otras, las siguientes:

- "Ladrón de cuello y corbata" "Borrón y cuenta nueva"

- "En el Perú, la justicia se compra” "Después te explico"

- "No te preocupes, yo me encargo de todo"

- "Vacas sagradas"

- "Papelito manda"

- "De mañas y artimañas mucho saben las alimañas" "La manzana podrida corrompe a las demás" "Olor a pescado podrido"

- "Miente, miente que algo queda"

- "Las medias verdades son peor que las mentiras" "Con tal que me dé de comer que robe nomás" "Repartija: "Repartirse la torta"

- "Rabo de paja" "Mamadera del Estado"

- "Honorarios de éxito"
- "Habrá robado pero ha hecho obra"

- "El dinero que robó no era del Estado; era del narcotráfico" "El mejor cliente es el Estado"

- “¿Quién no ha robado?". "Todos roban" "¿Y, cuál es la mía?"

- "Soy su hermano pero no sé nada" "Hecha la ley, hecha la trampa"

- "Para mis amigos todo y para mis enemigos la ley" "Se levantó el Perú en ruedas"

- "Romper la maño". Cutra. "Coimisión". "Movida"

- "Usted dirá, con cuanto nos apoya" "Planillas ocultas". "Planillas doradas" "Es conversable"

- "El honor es su divisa y el empalme su sonrisa" "Habla, ¿cómo es? Tú dirás. Yo sólo escucho" "Tragamonedas" (Policía corrupto)

- "Hemos hecho un faenón hermano" "Rata, ratón o insecto"

- "Aceitar". "Operar". "Bisturí". "Cocodrilos del mismo charco" "Ladrón de cuatro esquinas "Ladrón de siete suelas"

- "Cómo le gusta la mermelada"

\section{Imagenología de la clase política peruana}

Sin caer en abusivas generalizaciones, los "vladivideos", "vladiaudios", "petroaudios", "petromails", comunicaciones y agendas, han revelado que no pocos miembros de las cúpulas dirigentes del país: políticas, tecnocráticas, empresariales, militares y sociales, poseen comportamientos anéticos:

$\begin{array}{lll}\text { Doble juego } & \text { Avaricia } & \begin{array}{l}\text { Carencia de } \\ \text { identidad }\end{array} \\ \text { Doble moral } & \text { Indolencia } & \text { Oportunismo } \\ \text { Doble cara } & \text { Manipulación } & \begin{array}{l}\text { Felonía } \\ \text { Incapacidad de } \\ \text { sentir culpa }\end{array} \\ \text { Amoralidad } & \text { Artimañas } & \\ \text { Sed de poder } & \text { Malas artes } & \end{array}$




\section{Impunidad}

La corrupción no deja huella, los destapes sólo son la punta del iceberg de la gangrena moral del Perú donde casi todo se desconoce. La justicia comúnmente exculpa a los corruptos y muy pocas veces los condena. La Procuraduría Anticorrupción, la Contraloría, la Policía, el Ministerio Público y el Poder Judicial, a menudo, son comprados o escamoteados. Los controles no funcionan. Comúnmente la justicia sólo opera cuando hay escándalo mediático.

\section{Síndrome de corruptela política}

En el escenario político global, nacional y local, es común comprobar el siguiente síndrome psicopatológico:

\begin{tabular}{|c|c|}
\hline Maquiavelismo & $\begin{array}{l}\text { Demolición de los } \\
\text { valores éticos y morales }\end{array}$ \\
\hline Mendacidad & Sed de poder \\
\hline Mecida & Histrionismo patético \\
\hline Mesianismo & Perfidia \\
\hline $\begin{array}{l}\text { Servilismo y } \\
\text { obsecuencia }\end{array}$ & Cinismo \\
\hline Golpismo & Indolencia \\
\hline Gobierno de cúpula & Soberbia \\
\hline Corrupción & Desinformación \\
\hline Polarización política & $\begin{array}{l}\text { Fragmentación social } \\
\text { Enquistamiento en el } \\
\text { poder }\end{array}$ \\
\hline Impunidad Autocracia & Derrumbe moral \\
\hline
\end{tabular}

\section{Semiología}

- Espionaje telefónico "Chuponeo". "Pinchar"

Interceptación telefónica clandestina para grabar las conversaciones privadas de las personas, violando su intimidad, con propósitos perversos. - Videoespionaje "Ampay". "Vladivideos".

Grabación fímica clandestina de la vida íntima o privada de las personas para luego exponerlas al escarnio público o chantajearlas.

- Limpieza de imagen "Blanqueo". "Lavar la cara"

Maniobras y estrategias manipulatorias dirigidas a limpiar la imagen de personajes públicos caídos en descrédito. Por ejemplo: campaña mediática desplegada para presentar ante la opinión pública al dominicano Fortunato Canaán, como un bien intencionado empresario dispuesto a invertir en el Perú en los rubros de extracción de petróleo, construcción de hospitales y cárceles, energética, etc.; ocultando que lo hacía utilizando a un lobbista posicionado en las altas esferas del poder político para evadir las licitaciones y, por ende, al órgano de control público correspondiente: Consejo Superior de Contrataciones y Adquisiciones del Estado (CONSUCODE).

- Soborno "Romper la maño". "Aceitar"

Acción de ofrecer dinero, dádivas o prebendas a alguien, para obtener de él un favor o beneficio. Pago que se hace a una autoridad para que simule desconocer la trasgresión y de este modo impedir que se aplique la Ley, logrando la impunidad.

Ejemplo: Sendos videos permitieron visualizar en la televisión el pago que efectuó el eximio corruptor Vladimiro Montesinos Torres a políticos, empresarios y directores de diarios, para comprar su conciencia política; así como a determinados medios de comunicación y ponerlos al servicio de la campaña rereelecionista de su mentor y jefe político, Alberto Fujimori. 
- Tráfico de influencias "Vara". "Padrinazgo"

Es la utilización de un cargo público para obtener beneficios propios por sobre los intereses sociales o nacionales. V.gr. Todo un gabinete ministerial tuvo que renunciar por el escándalo mediático y social del caso "petrogate" (negociado de concesión de lotes para exploración de petróleo).

- Lavado de dinero "Blanqueo de dinero"

Legalizar el dinero mal habido mediante la utilización de organizaciones de fachada y/o utilización de testaferros. El alcalde de Pucallpa y un empresario aerocomercial fueron encarcelados acusados de lavado de activos en cantidades fabulosas.

- Tráfico ilícito de drogas "Narcotráfico". "Narcococaleros". "Narcos". "Narcopaís"

Negocio con drogas ilícitas a través de organizaciones mafiosas que ganan pingües cantidades de dinero sucio. Cultivo e intento de legalización de los cultivos de hoja de coca para las organizaciones mafiosas. Por ejemplo: las zonas rojas: Cusco, Huánuco, el VRAE (Valle de los ríos Apurímac y Ene). Igualmente, intensas campañas publicitarias destinadas a impulsar la legalización de la marihuana orquestadas por organizaciones camufladas y apoyadas por personalidades desinformadas.

- Contrabando Mercado negro. "Contra"

Introducción y venta clandestinas de mercaderías prohibidas o sometidas a derechos arancelarios demasiado elevados, defraudando al tesoro público.
- Corrupción de funcionarios "Coima". "Coimisión"

Sobornar funcionarios públicos para interferir o manipular su conducta funcional en beneficio de ocultos intereses particulares. Caso "petrogate".

- Enriquecimiento ilícito "Peces gordos"

Acumulación de dinero mal habido con escandalosos signos exteriores de riquezas, producto de negocios turbios, operaciones económicas ilegales y aprovechamiento ventajista de las posiciones de poder.

- Tránsfugas "Vendidos". "Otorongos"

Personajes políticos que venden su conciencia política al mejor postor, traicionando a su electorado o seguidores. Por ejemplo: transfuguismo de congresistas. "Otorongo no come Otorongo".

- Planillas doradas Mamadera". "Burocracia dorada". "Comechao"

Sueldos burocráticos exorbitantes que se asignan a sí mismos los burócratas de las cúpulas del poder mediante planillas secretas o camufladas.

- Lobby "Contactos". "Relaciones". "Honorarios de éxito"

Grupo no convencional que ejerce presión sostenida sobre autoridades y funcionarios públicos, para obtener negocios ventajosos con el Estado. Actúan en base a influyentes contactos partidarios, empresariales y sociales. Por ejemplo: lobista prófugo que se entregó voluntariamente a la justicia luego de 38 días de clandestinidad, por el caso del "petrogate". 
- Sobrevaloración y subvaluación "Cutra"

Dolo consistente en la alteración de los precios de bienes y servicios según la conveniencia de los proveedores, en contubernio con los responsables de adquisiciones al interior de las instituciones.

\section{- Malversación}

Delito que cometen las autoridades o funcionarios que sustraen o consienten que un tercero sustraiga caudales o efectos públicos que tienen a su cargo. Uso de dinero del tesoro público para fines no previstos, no presupuestados ni programados.

\section{- Mecer "Huevear"}

Entretener a alguien con engaños. Por ejemplo: encarcelar a los corruptos por un tiempo corto para simular justicia, luego dejarlos libres para que disfruten de lo robado por el resto de su vida.

\section{- Poder mafioso "Capos".}

Red de personajes corruptos que actúan en forma orquestada, concertada y a la sombra del poder político, administrativo o social, con la finalidad de perpetrar sus fechorías o de protegerse de la acción de la justicia en aras de la impunidad o lenidad. Recurren a la artimaña, triquiñuela, componenda, patraña, extorsión, chantaje y aniquilamiento.

- Operativos psicosociales "Cortina de humo". "Arte del engaño". "Cojudeo Social"

Acciones encubiertas para demonizar o demoler a un adversario político. También alarmar, escandalizar o intimidar a la opinión pública, distrayendo su atención con impactos mediáticos de cobertura local, regional o nacional, para que se olvide del problema crítico de fondo. Ejemplo: La virgen que llora, el retorno de Sara Helen, presencia del curandero Texeira, histriónico operativo policial del ex presidente Fujimori simulando la captura de su siamés Montesinos.

\section{Secuelas}

Este trastorno espiritual maligno acarrea consecuencias sociales funestas, a menudo, irreversibles. Principalmente:

\begin{tabular}{|c|c|}
\hline $\begin{array}{l}\text { Anomia social } \\
\text { patológica. }\end{array}$ & $\begin{array}{l}\text { Prelación de } \\
\text { los antivalores } \\
\text { Insensibilidad. }\end{array}$ \\
\hline $\begin{array}{l}\text { Deshumanización } \\
\text { colectiva. }\end{array}$ & $\begin{array}{l}\text { Saqueo del dinero } \\
\text { público por la } \\
\text { autoridad. }\end{array}$ \\
\hline $\begin{array}{l}\text { Injusticia e inequidad } \\
\text { social. }\end{array}$ & Adicción al dinero. \\
\hline Canibalización. & Estado Fallido. \\
\hline $\begin{array}{l}\text { Lumpenización } \\
\text { gremial, colectiva e } \\
\text { institucional. }\end{array}$ & $\begin{array}{l}\text { Brechas sociales } \\
\text { abismales. } \\
\text { Fundamentalismo } \\
\text { ideológico. }\end{array}$ \\
\hline $\begin{array}{l}\text { Pérdida de valores de } \\
\text { vida. }\end{array}$ & Confrontación social.. \\
\hline $\begin{array}{l}\text { Violencia colectiva } \\
\text { Cúpulas gremiales } \\
\text { enquistadas. }\end{array}$ & $\begin{array}{l}\text { Antros de corrupción. } \\
\text { Falta de oportunidades. } \\
\text { Estado Perverso }\end{array}$ \\
\hline Minusvalía colectiva. & NarcoEstado. \\
\hline $\begin{array}{l}\text { Redes de poder oculto. } \\
\text { Castas privilegiadas. }\end{array}$ & $\begin{array}{l}\text { Fragmentación social } \\
\text { Autodestrucción. }\end{array}$ \\
\hline $\begin{array}{l}\text { Alta conflictividad } \\
\text { social. }\end{array}$ & $\begin{array}{l}\text { Heterodestrucción } \\
\text { masiva. }\end{array}$ \\
\hline Atraso social. & $\begin{array}{l}\text { Desesperanza } \\
\text { colectiva... }\end{array}$ \\
\hline $\begin{array}{l}\text { Pobreza y pobreza } \\
\text { extrema. }\end{array}$ & Mediocrecracia \\
\hline $\begin{array}{l}\text { Acumulación de } \\
\text { riqueza extrema en la } \\
\text { élite social. }\end{array}$ & $\begin{array}{l}\text { Delincuencia } \\
\text { institucionalizada. } \\
\text { Psicopatización social. }\end{array}$ \\
\hline
\end{tabular}


Discriminación social. Cultura tanática.

Envilecimiento.

Oscurantismo mental.

Sufrimiento colectivo.

Indignación social.
Crimen organizado.

Depredación de la

biodiversidad

Devastación ecológica.

Contaminación ambiental y sonora.

\section{Alternativas}

Para frenar y acabar con esta gangrena social se formulan las siguientes propuestas: Saneamiento integral de la administración de justicia.

- Poner fin a la impunidad mediante una legislación que penalice la corrupción como delito de lesa humanidad.

- Que las organizaciones de derechos humanos contemplen el sufrimiento del pueblo como consecuencia de la corrupción y se sumen a la instrumentalización de una legislación drástica.

- Que las organizaciones internacionales de la más alta jerarquía apoyen resueltamente a los gobiernos en su lucha contra la corrupción.

Cesar la retórica de la mera condena e implementar una política de hechos que ataque el problema desde sus raíces.

- Crear un sistema anticorrupción con jueces, fiscales y policías probos; con autonomía administrativa y económica.

- Vertebrar un vigoroso movimiento social anticorrupción sostenido, con apoyo político y económico en todo el país.

- Valorar la reserva moral de la sociedad.

- Educación humanista sustentada en valores democráticos, con paradigmas positivos. Impulsar el desarrollo humano sostenible.

- Movilización de la sociedad peruana contra la corrupción generalizada existente en el país y en pro de los valores éticos y morales

- Educar a los niños desde el hogar.

\section{REFERENCIAS BibLiográficAS}

1. Peña S. Reflexiones sobre la corrupción: patología mental, social, política y ética. Rev Neuropsiquiatr. 2013;76 (3):153-160.

2. Porras R. El legado Quechua. Indagaciones peruanas: Lima: Fondo Editorial UNMSM, 1999.

3. Quiroz A. Historia de la corrupción El legajo Quechua. Revista de la Universidad Católica del Perú. 1935;13:142-148.en el Perú. 1ed. Lima: Instituto de Estudios Peruanos e Instituto de Defensa Legal, 2013, 615 pp.

4. Castillo E. La conjura de los corruptos. Vol. $\mathrm{n}^{\circ} 1$. Narcotráfico. 1ed. Lima: Editorial Brasa; 2001.

5. Gonzales G. Los escaños de Montesinos. Testimonios de una entrega sin condiciones. 1ed. Lima: Fimart, 2001.

6. Jochamowitz L. Vladimiro, vida y tiempo de un corruptor. 1ed. Lima: El Comercio Ediciones, 2002.

7. Nizama M. La década dantesca del Perú. Visión de un psiquiatra. 1ed. Lima: Editorial Milla Batres, 2001.

8. Nizama M. Psicopatía Política: Caso Fujimori. Revista de Investigación en Psicología. 2009; 11(1):1136.

9. Ramírez R. Los jueces de Montesinos. La mafia fujimontesinista en el poder judicial. 1ed. Lima: Academia de Magísteres y Doctores del Perú (AMADP); 2002.

10. Rospigliosi F. El arte del engaño: Las relaciones entre los militares y la prensa. 1ed. Lima: Tarea Asociación Gráfica Educativa, 2000.

11. Muñoz J. La psicopatía y su repercusión criminológica: Un modelo comprehensivo de la dinámica de personalidad psicopática. Madrid. Anuario de Psicología Jurídica. 2011;21: 57-68.

12. Millon T, Grossman S, Millon C, Meagher S, Ramnath R. Personality Disorders in Modern Life. 2ed. Nueva York: John Wiley \& Sons; 2001.

13. Santos G. Estados Fallidos: definiciones conceptuales. Servicio de investigación y análisis, Subdirección de Política Exterior. Cámara de diputados de México, 2009. 